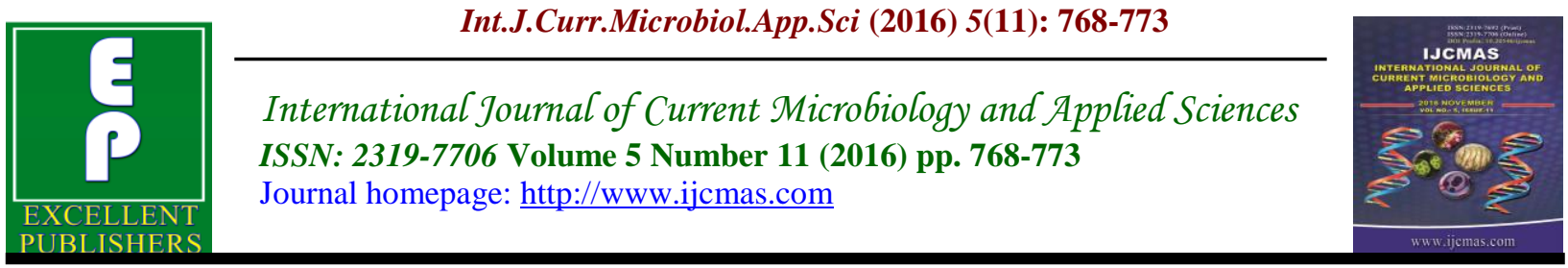

Original Research Article

http://dx.doi.org/10.20546/ijcmas.2016.511.088

\title{
Prevalence and Detection of Tomato Leaf Curl Virus from Low Altitude Subtropical Areas of Jammu and Kashmir
}

\author{
Ranbir Singh*, V.K. Razdan and Manika Sharma \\ Division of Plant Pathology, FOA, main campus Chatha of SKUAST-Jammu- 180009 \\ *Corresponding author
}

\begin{tabular}{|c|c|}
\hline & A B S T R A C T \\
\hline $\begin{array}{l}\text { Ke y w o r d s } \\
\text { ToLCV } \\
\text { (Tomato leaf curl } \\
\text { virus), } \\
\text { Disease Incidence, } \\
\text { Jammu region. }\end{array}$ & \multirow{3}{*}{$\begin{array}{l}\text { Tomato production in Jammu and Kashmir has suffered considerable losses in } \\
\text { yield and fruit quality due to infections of tomato leaf curl virus (ToLCV). The } \\
\text { survey data revealed that the ToLCV was present in almost all parts of Jammu, } \\
\text { Kathua and Udhampur districts. The percentage of Disease incidence ranged from } \\
29.60-47.20 \text { per cent. The overall incidence of the disease ranged from } 20.0-37.6 \\
\text { per cent in Jammu district while in Kathua and Udhampur districts, the incidence of } \\
\text { the disease was 33.6-44.8 and } 25.6-33.6 \text { per cent respectively. The results indicated } \\
\text { that ToLCV is the predominant and most important viral pathogen in tomato } \\
\text { production systems in Jammu region of Jammu and Kashmir. Amplicon of } 700 \mathrm{bp} \\
\text { was obtained from the infected samples collected from different locations. }\end{array}$} \\
\hline Article Info & \\
\hline $\begin{array}{l}\text { Accepted: } \\
26 \text { October } 2016 \\
\text { Available Online: } \\
\text { 10 November } 2016\end{array}$ & \\
\hline
\end{tabular}

\section{Introduction}

Tomato (Lycopersicon esculentum Mill.) is an important and most widely grown vegetable crop in India. Virus diseases are the major production constraints. Among the virus diseases, tomato leaf curl disease is the important and devastating which limit the tomato production. The disease has become a major limiting factor and challenge to farmers and scientists and whiteflytransmitted geminiviruses belonging to the genus Begomovirus of the family Geminiviridae. This disease is the major constraint in improving tomato production in India (Vasudeva and Samraj, 1948; Sastry and Singh, 1973; Saikia and Muniyappa, 1989; Harrison et al., 1991). The incidence of ToLCV in tomato growing areas of Karnataka ranged from 17-100 per cent in different seasons (Saikia and Muniyappa, 1989). Yield loss exceeds 90 per cent, when infection occurred within four weeks after transplanting in the field (Sastry and Singh, 1973; Saikia and Muniyappa, 1989). In Jammu region of Jammu and Kashmir the area and production of tomato is 1,280 ha and 23,550 metric tonnes respectively, with the productivity of 18.40 tones/ha but the average disease incidence of 89.04 percent and yield reduction of 82.42 per cent has been reported (Mahajan, 2001). The best method for the management of plant viruses is their timely detection and identification 
and In Jammu region of Jammu and Kashmir no work regarding the detection of the virus through molecular tools had been done. Considering that, the present work is initiated in identification of Tomato leaf curl virus and development of reliable detection method suitable for development of various management strategies.

\section{Materials and Methods}

\section{Survey}

A roving survey was under taken to know the incidence of tomato leaf curl virus disease (ToLCV) in different parts of low altitude subtropical areas of Jammu, Kathua, and Udhampur districts during summer 2015. All the plants in the selected plot area $(10 \mathrm{~m} \times 10 \mathrm{~m})$ of the fields were counted and the number of plants showing leaf curl symptoms were recorded separately to calculate per cent disease incidence. The overall disease incidence was recorded based on symptoms The percentage of Disease Incidence was calculated by

Percent
incidence $\quad$ disease $=\frac{\text { No. of infected plants }}{\begin{array}{l}\text { Total No. of Plants } \\ \text { observed }\end{array}} \times 100$

counting the number of diseased plants exhibiting characteristic symptoms of the disease and by using following formula.

\section{Sample collection and DNA isolation}

Infected tomato leaf samples were placed in labeled polyethylene bags and transported to the laboratory for processing. The DNA from the infected leaf samples was later isolated. Hundred $\mathrm{mg}$ of leaf tissue was crushed in liquid nitrogen and was incubated with $850 \mu \mathrm{l}$ of $\mathrm{CTAB}(\mathrm{pH} 8.0)$ at $65^{\circ} \mathrm{C}$ in serological water bath for $1 \mathrm{hr}$ with regular inversions. After that $24: 1$ solution of chloroform: isoamyl alcohol was added to separate out the chlorophyll and protein content after centrifugation at $10000 \mathrm{~g}$ for 20 min. The supernatant was mixed with $650 \mu 1$ of isopropyl alcohol to precipitate the DNA. After centrifugation, this precipitated DNA was washed with $70 \%$ and 100 per cent alcohol and after complete drying of ethanol; the DNA was dissolved in $100 \mu$ l of $1 \mathrm{x}$ TE solution and was stored at $-20^{\circ} \mathrm{C}$ for further analysis.

\section{PCR detection}

For the detection of tomato leaf curl virus the PCR was performed in a $25 \mu 1$ reaction mix where $2 \mu$ of the DNA taken as template was amplified.The reaction mix finally consisting of $200 \mu \mathrm{M}$ each dNTPs, primers $(20 \mathrm{pmol}), 1.5 \mathrm{mM} \mathrm{MgCl}_{2}$ and $10 \mathrm{X}$ PCR buffer. The PCR cycles set were, initial one cycle of denaturation at $94^{\circ} \mathrm{C}$ of $5 \mathrm{~min}$ followed by 35 cycles of denaturation at $94^{\circ} \mathrm{C}(1 \mathrm{~min})$, annealing at $50^{\circ} \mathrm{C}(1 \mathrm{~min})$ and extension at $72 \mathrm{C}$ for $1 \mathrm{~min}$; the final extension was given at $72^{\circ} \mathrm{C}$ for $10 \mathrm{~min}$.

\section{Gel Electrophoresis}

The amplified PCR products were analyzed on one per cent agarose gel containing ethidium bromide $\left(10 \mathrm{mg} \mathrm{ml}^{-1}\right)$. The agarose gel $(1 \%)$ was prepared in 1X TAE solution and the samples were electrophoresed by supplying voltage @ 5V cm-1. The $1 \mathrm{~kb}$ ladder (Fermentas) was used as marker to identify the size of the amplified product.

\section{Results and Discussion}

\section{Disease Incidence of Tomato leaf curl virus from different locations}

The survey data revealed that the ToLCV was present in almost all parts of Jammu, Kathua and Udhampur districts. The 
percentage of Disease incidence in case of Tomato leaf curl virus ranged from 29.6047.20 per cent respectively (Table. 1 and Table.2).Maximum incidence of ToLCV was observed in $(47.22 \%)$ was recorded in Udheywalla of Jammu district while minimum incidence was observed in
(29.60\%) was observed in Akhnoor. In Jammu district, the disease incidence ranged from 29.60-47.20 per cent with a mean of 24.44 per cent. The maximum disease incidence of $47.20 \%$ was recorded in Udheywalla while minimum in $29.60 \%$ in Akhnoor.

Table.1 Percentage of Disease Incidence of Tomato leaf curl virus in Low altitude subtropical locations of Jammu Division

\section{Per cent disease incidence of Tomato leaf curl virus at different location of Jammu division}

\begin{tabular}{|c|c|c|}
\hline & Location & Percent disease incidence (\%) \\
\hline \multirow{6}{*}{ Jammu } & Ponichak & 35.20 \\
\hline & Akhnoor & 29.60 \\
\hline & Marh & 45.60 \\
\hline & Udheywalla & 47.20 \\
\hline & Mean & \\
\hline & Range & $29.60-47.20$ \\
\hline \multirow[t]{6}{*}{ Kathua } & Mahrin & 39.20 \\
\hline & Chadwal & 37.60 \\
\hline & Kagri Khokyal & 36.00 \\
\hline & Rajbagh & 31.20 \\
\hline & Mean & \\
\hline & Range & $31.20-39.20$ \\
\hline \multirow[t]{6}{*}{ Udhampur } & Basantgarh & 42.40 \\
\hline & Chenani & 32.00 \\
\hline & Ramnagar & 38.40 \\
\hline & Tikri & 33.60 \\
\hline & Mean & \\
\hline & Range & $32.00-42.40$ \\
\hline $\begin{array}{l}\text { Over all } \\
\text { range }\end{array}$ & & $29.60-47.20$ \\
\hline
\end{tabular}


Table.2 Average Disease Incidence of Tomato leaf curl virus from different Districts of Jammu

\begin{tabular}{|l|l|l|l|l|}
\hline \multirow{2}{*}{ S.No } & \multirow{2}{*}{ District } & \multicolumn{3}{|c|}{ Average \% Disease Incidence } \\
\cline { 3 - 5 } & & Minimum & Maximum & Average \\
\hline 1. & Jammu & 29.6 & 47.2 & 39.4 \\
\hline 2. & Udhampur & 32.0 & 42.4 & 36.0 \\
\hline 3. & Kathua & 31.2 & 39.2 & 36.6 \\
\hline
\end{tabular}

Fig.1

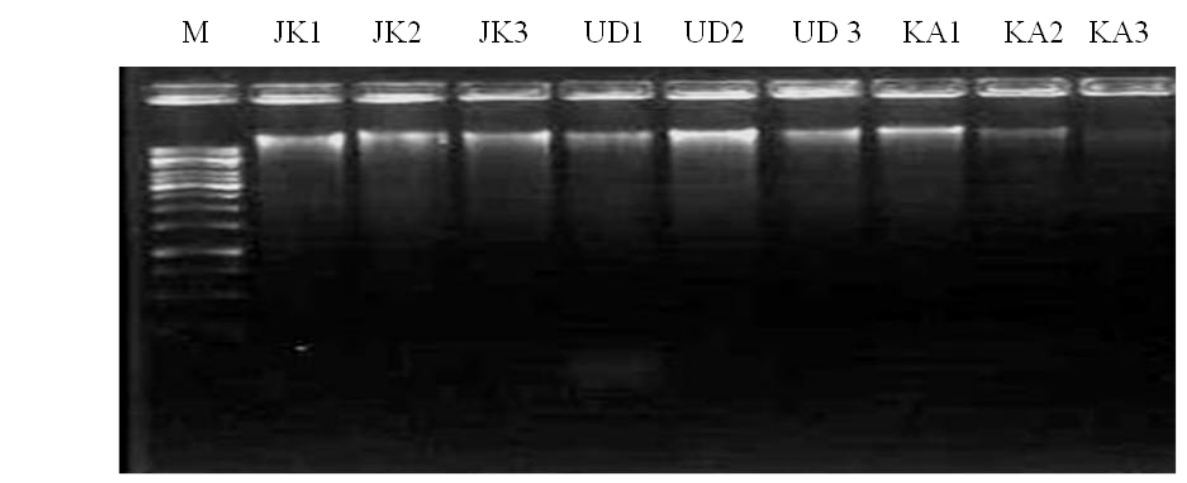

Fig.1Gel photograph showing DNA isolated from different locations of Jammu, Udhampur and Kathua

\section{Fig.2}

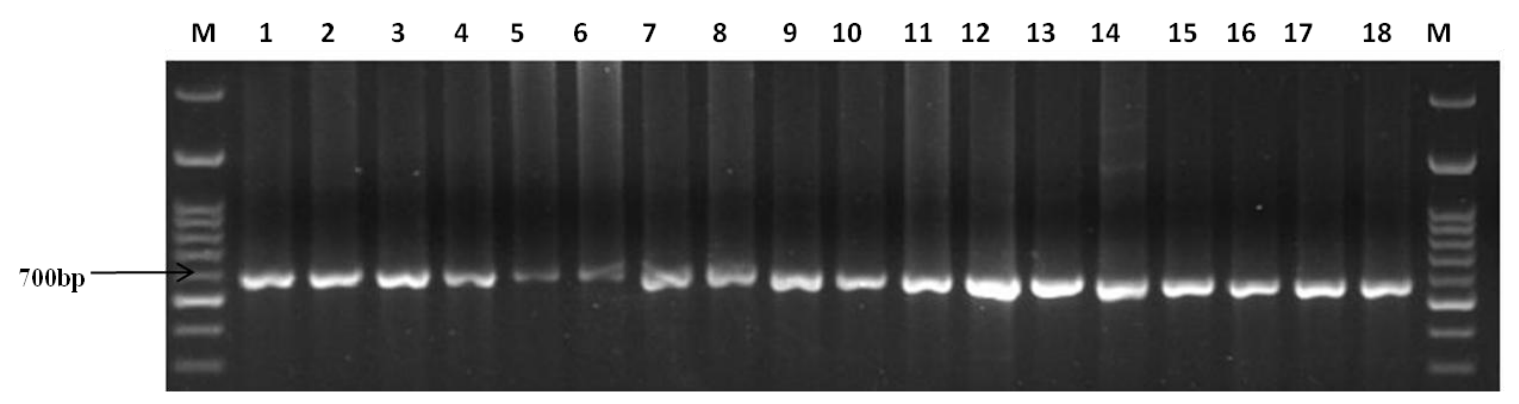

Fig 2 Gel photograph showing amplification of coat protein gene(AVR) region of ToLCV 700bp.M-Marker, 1-Ponichak, 2-Akhnoor, 3-Marh, 4-Udheywalla, 5-Mahrin, 6-Chadwal, 7- Kagri , 8-Rajbagh, 9-Basantgarh,10- Chenani, 11-Ramnagar, 12-Tikri, 13-Sobka ,14-Thathi, 15Gajansoo, 16-Panjore, 17-Basantgarh,18- Mahrin, M-Marker

In Kathua district the percentage of Disease incidence was $39.20 \%, 37.60 \%, 36.00 \%$, $31.20 \%$ in Mahrin, Chadwal, Kagri Khokyal, Rajbagh areas respectively While in Udhampur district maximum percentage of Disease Incidence (42.40\%) was recorded in Basantgarh while minimum was recorded in Chenani $(32.00 \%)$. The overall incidence of the disease ranged from 20.0-37.6 per cent in Jammu district while in Kathua and Udhampur districts, the incidence of the disease was 33.6-44.8 and 25.6-33.6 per cent respectively. The results revealed that the per cent disease incidence varied from location to location. However, the disease (ToLCV) and the vector, Bemisia tabaci 
were found in almost all the tomato fields surveyed. The higher incidence during summer months could be attributed to higher whitefly population and high temperature. Seetharama Reddy (1978) also observed 638 per cent

ToLCV incidence during winter months and 25-86 per cent during summer months. Similar observations were made by Saikia and Maniyappa (1989) and Raghavendra (2002) who recorded $24-100$ per cent ToLCV incidence. Saikia and Muniyappa (1989) also recorded 17.53 per cent incidence of ToLCV in some tomato growing areas of Karnataka during JulyNovember. Singh and Reddy (1993) from two years survey reported 60-100 per cent ToLCV incidence from tomato growing areas of Karnataka).

\section{Molecular detection}

Tomato leaf curl viral DNA was amplified in PCR using ToLCV specific primers, AV1 F ATGGCGAAGCGACCAG and AV2 R:TTAATTTGTGACCGAATCAT. The virus was detected through PCR from field collected tomato samples (amplification of 1 $\mathrm{kb}$ fragment) which showed the amplification of size $700 \mathrm{bp}$ after gel electrophoresis which was further reevaluated. Polymerase Chain Reaction (PCR) method amplifies a specific DNA sequence that is present between two regions of known nucleotide sequence (Innies et al., 1990) and is widely used. PCR technique over comes problems associated in serological detection methods and has been utilized successfully to detect gemini viruses (Deng et al., 1994; Rojas et al., 1993 and Mehta et al., 1994). The PCR technique over comes the problems associated with serological detection methods and had been utilized successfully to detect gemini viruses (Deng et al., 1994), Rojas, et al., 1993, and Mehta et al., (1994).

\section{Acknowledgement}

The author is highly thankful to the Department of Biotechnology (Govt. of India) for funding the project and carrying out this work.

\section{References}

Deng, A., Mcgrath, P.F., Robinson, D.J. and Harrison, B.D. 1994. Detection and differentiation of whitefly transmitted gemini viruses in plants and vector insects by the polymerase chain reaction with degenerate primers. Annals of Appl. Biol., 125: 327-336.

Harrison, B.D., Muniyappa,V., Swanson, M.M., Roberts, I.M. and Robinson, D. J., 1991, Recognition and differentiation of seven whitefly transmitted gemini viruses from India and their relationships to African cassava mosaic and Thailand mungbean yellow mosaic viruses. Annals of Appl. Biol., 118: 299-308.

Innies, M.A., Gelford, D.H., Senisky, J.J. and White, T.T. 1990. PCR protocols, A guide to methods and application, Academic press, New York.

Mehta, P., Jeffrey, A., Wayman, M. K., Nakhla and Maxwell, D.P. 1994. Polymerase chain reaction detection of of viruliferous Bemisia tabaci with two tomato infecting geminiviruses. Indian J. Economic Entomol., 87: 1285- 1290.

Mahajan, R.2001. Investigation on leaf curl virus of tomato. M.Sc. thesis in Plant Pathology. Sher-e-Kashmir University of Agricultural Sciences and Technology, Jammu.

Raghavendra, A.S. 2002. Histology, Biochemical studies and management of tomato leaf curl. M.Sc (Agri) Thesis, UAS, Dharwad, pp. 63

Rojas, M.R., Gilbertson, R.L., Russell, D.R. 
and Maxwell, D.P. 1993.Use of degenerate primers in the polymerase chain reaction to detect whitefly transmitted gemini viruses. Plant Dis., 77: 340-347.

Sastry, K.S.M. and Singh, S.J. 1973. Assessment of loss in tomato by tomato leaf curl virus. Indian J. Mycol. Plant Pathol., 27: 274-297.

Saikia, A.K. and Muniyappa, V. 1989. Epidemiology and control of tomato leaf curl virus in Southern India. Tropical Agri., 66: 350-354.

Seetharama Reddy, K. 1978. Studies on leaf curl disease of tomato (Lycopersicon esculentum Mill.). Ph.D Thesis, UAS, Bangalore, India, pp. 134.

Saikia, A.K. and Muniyappa, V. 1989. Epidemiology and control of tomato leaf curl virus in Southern India. Tropical Agri., 66: 350-354.

Singh, S.J. and Reddy, M.K. 1993. Leaf curl virus disease of tomato and its management. Vatika from the seed and plant people, 2: 5-21.

Vasudeva, R.S. and Sam raj. 1948. Leaf curl disease of tomato. Phytopathol., 18: 364-369.

\section{How to cite this article:}

Ranbir Singh, V.K. Razdan and Manika Sharma. 2016. Prevalence and Detection of Tomato Leaf Curl Virus from Low Altitude Subtropical Areas of Jammu and Kashmir. Int.J.Curr.Microbiol.App.Sci. 5(11): 768-773. doi: http://dx.doi.org/10.20546/ijcmas.2016.511.088 